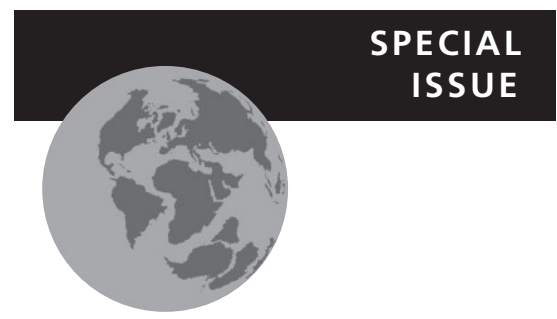

\title{
Towards a glacial-sensitive model of island biogeography
}

\author{
José María Fernández-Palacios ${ }^{1,2 *}$, Kenneth F. Rijsdijk ${ }^{3}$, Sietze J. Norder ${ }^{3}$, \\ Rüdiger Otto ${ }^{1}$, Lea de Nascimento ${ }^{1,2}$, Silvia Fernández-Lugo ${ }^{1}$, Even Tjørve ${ }^{4}$ \\ and Robert J. Whittaker ${ }^{2,5}$
}

${ }^{1}$ Island Ecology and Biogeography Research Group. Instituto Universitario de Enfermedades Tropicales y Salud Pública de Canarias (IUETSPC), Universidad de La Laguna, Tenerife, Canary Islands 38206, Spain, ${ }^{2}$ Conservation Biogeography and Macroecology Group, School of Geography and the Environment, South Parks Road, Oxford OX1 3QY, UK, ${ }^{3}$ Computation GeoEcology Group, Institute for Biodiversity and Ecosystem Dynamics \& Institute for Interdisciplinary Studies, University of Amsterdam, Sciencepark 904, 1098 XH Amsterdam, The Netherlands, ${ }^{4}$ Faculty of Economics and Organisation Science, Lillehammer University College, 2604 Lillehammer, Norway, ${ }^{5}$ Center for Macroecology, Evolution and Climate, Department of Biology, University of Copenhagen, Universitetsparken 15, DK-2100 Copenhagen, Denmark

${ }^{*}$ Correspondence: José María Fernández-Palacios, Island Ecology and Biogeography Research Group. Instituto Universitario de Enfermedades Tropicales y Salud Pública de Canarias (IUETSPC),

Universidad de La Laguna, Tenerife, Canary Islands, 38206 Spain.

E-mail: jmferpal@ull.es

\begin{abstract}
Although the role that Pleistocene glacial cycles have played in shaping the present biota of oceanic islands world-wide has long been recognized, their geographical, biogeographical and ecological implications have not yet been fully incorporated within existing biogeographical models. Here we summarize the different types of impacts that glacial cycles may have had on oceanic islands, including cyclic changes in climate, shifts in marine currents and wind regimes and, especially, cycles of sea level change. The latter have affected geographical parameters such as island area, isolation and elevation. They have also influenced the configurations of archipelagos via island fusion and fission, and cycles of seamount emergence and submergence. We hypothesize that these sea level cycles have had significant impacts on the biogeographical processes shaping oceanic island biotas, influencing the rates and patterns of immigration and extinction and hence species richness. Here we provide a first step toward the development of a glacial-sensitive model of island biogeography, representing the tentative temporal evolution of those biogeographical parameters during the last glacial cycle. From this reasoning we attempt to derive predictions regarding the imprint of sea level cycles on genetic, demographic or biogeographical patterns within remote island biotas.
\end{abstract}

\section{Keywords}

Climate change, extinction, immigration, island biogeography, island theory, oceanic islands, Pleistocene, sea level fluctuations, species richness.

\section{INTRODUCTION}

\section{The dynamic equilibrium model}

Following its introduction by MacArthur \& Wilson (1963, 1967), the equilibrium theory of island biogeography (ETIB) became the ruling paradigm in island biogeography. The theory asserts that, in general, islands tend towards a state of equilibrium between three fundamental processes - immigration, speciation and extinction - which generate predictable patterns of species diversity and turnover on islands. The rates of these processes are posited to vary in response to distance from source pools (influencing immigration rates) and island area (influencing extinction rates). Although the speciation rate was

C 2015 John Wiley \& Sons Ltd hypothesized to increase as a contribution to island diversity in remote, large (oceanic) islands (MacArthur \& Wilson, 1963, p. 378), it was not included in MacArthur and Wilson's famous graphical model and is thus nearly forgotten by most users of their theory.

Appreciation of the utility of the ETIB as a strict explanatory model for species diversity patterns has been mixed (e.g. Gilbert, 1980; Schoener, 2010) and its equilibrium hypothesis, as originally defined, has even been argued to be unfalsifiable (Simberloff, 1976; see Warren et al., 2015, for a comprehensive synthesis). One of the strengths of the ETIB is its simplicity, yet this is also a limitation as it fails to incorporate the interplay of several other environmental factors that impact on species diversity on oceanic islands. A number of additions (or exten- 
sions) to the ETIB have been proposed to increase its realism. These modifications include the 'rescue effect', which states that a lower degree of isolation also decreases the extinction rate because immigrants reinforce extinction-prone populations (Brown \& Kodric-Brown, 1977; Wright, 1985), and the 'targetarea effect', which states that larger area (island size) also affects the immigration rate as the island becomes a larger target for passive or active immigrants (Gilpin \& Diamond, 1976; Lomolino, 1990).

\section{Towards disequilibrium models}

Although explicit in MacArthur \& Wilson's $(1963,1967)$ theorization, and thus far from being a new realization, several authors (Heaney, 2000; Lomolino, 2000) have more recently highlighted the importance of speciation, which across large time-scales (several million years) modifies the effect of both distance and area on species richness, and on endemic species richness in particular. Evolutionary dynamics act through the inherent ontogeny of the speciation process itself and through changes in island geography (e.g. Johnson et al., 2000; Stuessy, 2007; Whittaker et al., 2008; Chen \& He, 2009; Rosindell \& Phillimore, 2011). On hot-spot islands (such as the Azores, the Canaries, the Galápagos and Hawaii) the speciation rate over time is expected to show a unimodal ('humpbacked') pattern because of the limited lifetime of the islands themselves (e.g. Stuessy, 2007; Whittaker et al., 2008). However, during such lengthy time periods, most oceanic islands experience important and often cyclical geological and climatic changes that will influence the biological processes. The changes in island geography involve not only size changes but also the formation of land bridges (Heaney, 2000), the merging or breaking-up of islands (Ali \& Aitchison, 2014; Rijsdijk et al., 2014) or the completion of hot-spot oceanic island life cycles from emersion to submergence (Whittaker et al., 2008, 2010). Accordingly, Heaney (1986) proposed a dynamic-disequilibrium model in which the equilibrium in species richness is rarely achieved on islands because of constantly changing physical conditions (geological activity and climate change). The notion of the spatio-temporal dynamics of island geography together with the speciation processes signals the transition from equilibrium to disequilibrium models of island biogeography (see Heaney et al., 2013).

\section{Island ontogeny and the general dynamic model of oceanic island biogeography}

The ETIB (MacArthur \& Wilson, 1967) plus further embellishments (Brown \& Kodric-Brown, 1977; Lomolino, 1990), as well as speciation-sensitive models (Heaney, 2000; Lomolino, 2000), approximate islands as static entities with constant values of area, isolation and archipelagic configuration through time. In practice, even very young volcanic islands can vary their geographical attributes in a very short time (e.g. Surtsey, which emerged in 1963, has already lost half of its area), while dynamism is the general rule over longer, geological, time-scales (>10 kyr), where regional geological processes affect oceanic islands (island ontogeny) and supra-regional or even global climatic processes (Pleistocene glacial cycles) seriously compromise the perception of static islands (Heaney et al., 2013).

Although several authors have underlined the consequences of past geological and climatic dynamism for island biodiversity (e.g. MacArthur \& Wilson, 1967; Diamond, 1972; Wilcox, 1978; Price \& Elliott-Fisk, 2004), arguably the first island biogeographic model to include a temporal element was Whittaker et al.'s $(2008,2010)$ general dynamic model (GDM), where the concept of evolution of oceanic islands (ontogenetic stages sensu Stuessy, 2007) was introduced.

In the GDM, which primarily focuses on hot-spot oceanic islands, island age is considered as a key factor determining species diversity, while variation in the speciation rate is driven largely by the availability of unoccupied ecological niches, which is highest during the early stages of an island's development when species numbers have not yet reached the maximum carrying capacity. Species numbers, and richness and the proportions of single-island endemics, are therefore predicted to follow a hump-shaped trend, increasing during island emergence (youth), attaining their zenith at maturity (maximum topographic complexity, when intra-island allogenesis is at a peak) and finally decreasing during island submergence (senescence), resulting in a guyot (Wilson, 1969). Although positive evidence supports the general validity of this model (Bunnefeld \& Phillimore, 2012, Cameron et al., 2013), the GDM remains a simplified representation of island (geological and biological) dynamics and does not explain all the complexity (Borges \& Hortal, 2009).

\section{Environmental processes affecting insular dynamics}

Islands in oceanic settings are highly dynamic entities, subject to different major geological-climatic processes which vary in origin and time-scale, and it is well known that these processes influence species diversity patterns (Whittaker \& Fernández-Palacios, 2007). From the longer-lasting to more ephemeral, these processes include (Table 1): (1) continental drift (plate tectonics), which extends over tens to hundreds of millions of years; (2) oceanic island ontogeny, extending from tens to a few million years; (3) sea level transgression/regression cycles linked to glacial cycles (Pleistocene glaciations), extending from tens to hundreds of thousands of years; and (4) volcanic activity occurring in time frames from weeks to decades. Plate tectonics and island ontogeny affecting evolutionary processes over millions of years form one extreme of the time-scale of insular dynamics. The biogeographical and evolutionary effects of plate tectonics spanning up to hundreds of millions of years, as a result of translocation of islands and continental fragments and the formation of new arc islands, involving vicariance effects and affecting gene flow and evolution are well known (e.g. Gaina et al., 1998; Kearey et al., 2009). The hot-spot oceanic island ontogeny cycle generally spans a shorter period up to tens of millions of years, and how these dynamics affect species richness is currently under investigation. At the other extreme of the time-scale, and particularly associated with oceanic islands, are 


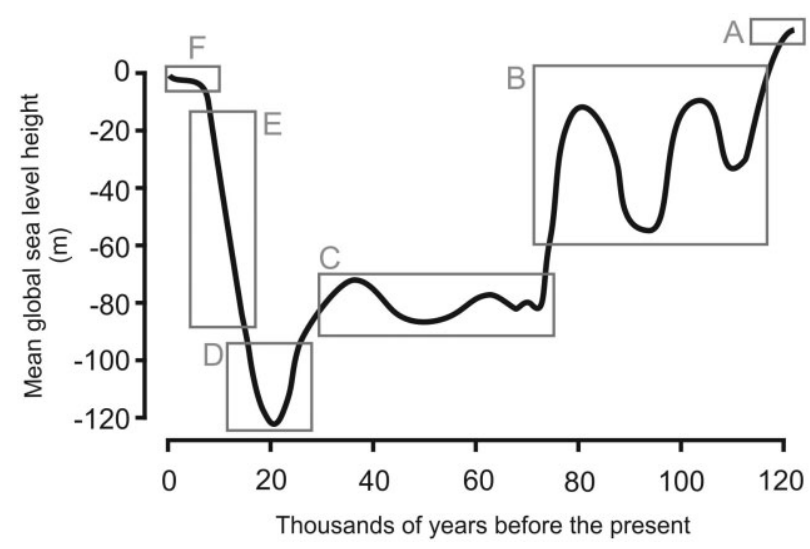

Figure 1 Global sea level change during the last 120,000 years. Generalized mean sea level reconstruction from 120 ka based on Camoin et al. (2004). Regions that are uncertain in Camoin et al. (2004) were interpolated linearly. In period A, Eemian interglacial sea levels were $10 \mathrm{~m}$ higher than today. In period B, sea levels fell with the onset of the glacial epoch, and warmer periods (interstadials) alternating with colder periods (stadials) led to sea level fluctuations between -20 and $-60 \mathrm{~m}$. In period $\mathrm{C}$ there was then a period of relative stability, although this may be an artefact of data sampling. Period D marks the extreme fall in sea level during the Last Glacial Maximum (LGM). Period E marks the rapid rise in sea level at the end of the LGM. Period F marks the stabilization of sea levels at present-day levels.

anomalous extreme events that act on ecological time-scales (days to weeks) related to volcanic activity (e.g. sterilization events; Whittaker et al., 1989) or geomorphological processes (e.g. landslides; Whelan \& Kelletat, 2003). Such extreme events may destroy mature ecosystems and directly cause species extinctions within weeks, but new pristine terrain created by these processes will offer new opportunities for species to thrive in areas of reduced interspecific competition. In between these evolutionary and ecological time-scales, the effects of glacial cycles and related sea level oscillations over thousands of years affect all islands and their biota globally (Table 1, Fig. 1). Sea level fluctuations driven by glacial cycles have occurred with periodicities of $c$. 40-100 kyr during the last 2.6 Myr (Bintanja et al., 2005, 2008; Rohling et al., 2009, 2010). The impact of these processes is particularly relevant for continental-shelf islands, which comprise most islands within the world's seas (Fernández-Palacios, 2010). Where the water depth separating them from their respective continent is shallow enough $(<c$.
$120 \mathrm{~m}$ ) these land-bridge islands reiteratively join and become isolated from the continents in response to eustatic changes in sea level (e.g. the British Isles, Taiwan). The biogeographical implications of these cycles of isolation and amalgamation have long been recognized (e.g. Diamond, 1972; Wilcox, 1978; Price \& Elliott-Fisk, 2004; Whittaker \& Fernández-Palacios, 2007).

\section{Aims of the paper}

It is evident that the island biodiversity we observe today results from geological and climatic processes that have modified the environment and geographical island settings over ecological and evolutionary time-scales. Herein we set out to incorporate the effects of these processes into a revised depiction of island theory, following the call by Lomolino (2000) to add complexity to island biogeographical models. Thus, the purpose of this contribution is to provide a hypothesis of how various Pleistocene events may have shaped island biodiversity in the past, while also presenting a set of testable predictions (see Box 1) that can be derived from it.

\section{BIOGEOGRAPHICAL CONSEQUENCES OF PLEISTOCENE GLACIAL EVENTS}

As a consequence of glacial cycles, three main types of geographical processes with biogeographical consequences can be distinguished on marine (land-bridge, micro-continental and true oceanic) islands: (1) sea level changes causing alterations in island areas, elevation, isolation and archipelagic configurations; (2) changes in climatic variables such as temperature and precipitation, which drive changes in elevational distributions of species and ecosystems; and (3) shifts in the direction, frequency and intensity of marine currents and wind systems influencing the connectivity of island systems with other land masses (Table 2).

\section{Changes in the geographical configurations of islands in relation to sea level transgression/ regression cycles}

Land-bridge islands are continental peninsulas that achieve their insular status in interglacial periods after sea level rise, although some may have been connected during every major glacial episode and some only perhaps once or twice when the very lowest sea levels have been reached. Studies dealing with the

Table 1 Major dynamic forces affecting marine islands.

\begin{tabular}{lllll}
\hline Island type & Plate tectonics $(100-1 \mathrm{Myr})$ & Island ontogeny $(10-1 \mathrm{Myr})$ & Glacial cycles $(100-1$ kyr $)$ & Volcanic activity $(<1 \mathrm{kyr})$ \\
\hline Continental-shelf islands & - & - & ++ & - \\
Continental fragments & ++ & - & + & - \\
Oceanic islands & + & ++ & + & ++ \\
\hline
\end{tabular}

- , relatively unaffected; +, moderately affected; ++, considerably affected. 


\section{Box 1 \\ Predictions of the glacial-sensitive model of island biogeography (some sources with evidence supporting the predictions are given in parenthesis)}

Predictions (1): Predictions linked to shifts in area and isolation.

(a) The immigration rate was lowest in the last interglacial (Eemian), when isolation was greatest, then rose throughout the last glaciation, achieving its highest rate in the LGM (least isolation) before decreasing again until the start of the present interglacial (Holocene).

(b) The extinction rate was highest in the last interglacial (Eemian), when island area was smallest, then dropped throughout the last glaciation until achieving its lowest rate in the LGM (largest area), before increasing again after the start of the present interglacial (Holocene).

(c) Palaeontological and palaeo-ecological research will make clear that several natural extinctions, caused by area reduction following sea level transgressions, occurred before human arrival to oceanic islands.

(d) Some very rare extant species should present signs of having passed a demographic collapse c. 15-12 ka resulting from range contraction due to sea level rise (González et al., 2014).

Predictions (2): Predictions linked to fusion/fission of islands.

(a) The fission of one large island into two or more smaller islands due to sea level rise will yield a high number of species shared among the once-attached islands, so that nearby islands subject to fusion/fission cycles will share more species than comparable island groups that were never physically linked (Macqueen et al., 2011; Rijsdijk et al., 2014).

(b) Genetic analyses will show that genetic divergence has occurred among populations that were split (allopatry) when islands were separated during the interglacial periods [Bidegaray-Batista et al., 2007; Ali \& Aitchison, 2014].

Predictions (3): Predictions linked to sea mounts emergence/submergence.

(a) Immigration and retrocolonization processes were favoured due to emergence of sea mounts during sea level regressions, thus enhancing connectivity.

(b) Fossil records on currently drowned seamount summits will reveal the presence (during the glacial events) of terrestrial plant species belonging to coastal ecosystems, shared with other nearby islands.

Predictions (4): Predictions linked to climatic shift.

(a) Fossil records will reveal the elevational shift of zonal ecosystems toward island summits during interglacial events and toward coasts during glacial events (Hotchkiss \& Juvik, 1999).

(b) Some very rare species that are currently restricted to climatic refugia should present signs of having experienced a demographic collapse caused by range contraction resulting from the disappearance of their ecosystem during the last deglaciation (Vaxevanidou et al., 2006).

(c) On some islands that currently lack ice sheets, geomorphological evidence will reveal the presence of ice sheets in the past (Porter, 1979).

Prediction (5): Prediction linked to shifts in marine currents and wind regimes.

(a) Shifts in marine currents and wind regimes have created new, bizarre dispersal windows, which should have left biotic signals in the form of retrocolonization (boomerang) events (Carine et al., 2004; Caujapé-Castells, 2004).

impact of glaciations have mostly focused on the 'relaxation' (reduction of richness to a new equilibrium) of their biotas following the most recent vicariance event (Diamond, 1972; Wilcox, 1978). Examples include the Sunda islands (Sumatra, Java and Borneo), which were connected to Indochina and the Malaysian Peninsula through Sundaland, the currently submerged South China Sea platform (occupying 1.8 million $\mathrm{km}^{2}$; Wang et al., 2009), the now submerged Sahul continent, comprising New Guinea, Australia and Tasmania, and the connection of mainland Britain with continental Europe through the low-lying tundra of Doggerland in the North Sea (Voris, 2000; Shennan \& Horton, 2002). Wallace (1880) documented this extensively in Island life.
In contrast to land-bridge islands, oceanic islands remain insular (or submerge and emerge as islands) during the glacial cycles, but their areas, configuration and isolation change over time depending on both the inherent geological dynamics of the islands and archipelagos and on their bathymetric configuration (e.g. Ali \& Aitchison, 2014). In general, sea level regressions cause a limited increase in area for steep-sloped young islands (Fig. 2), but for older, eroded volcanic islands, the effect of sea level cycles can be pronounced. These islands often are surrounded by shallow submarine platforms formed by extensive marine erosion and transportation. Thus, large increases in area are expected during sea level regressions, potentially resulting in the fusion of two or more neighbour- 
Towards a glacial-sensitive model of island biogeography

Table 2 Summary of the biogeographical consequences of changes in climatic and geographical parameters related to glacial cycles.
Figure 2 Changes in selected areas of the Canary Islands over the last glacial cycle (source Rijsdijk et al., 2014). We merged a detailed bathymetric model (with a $1 \mathrm{~km}^{2}$ resolution) with the sea level curve of Fig. 1. Fuerteventura merged several times with Lanzarote during the glacial period when sea levels lowered during stadial periods. While Gran Canaria increased in surface area, the area of the young island of El Hierro hardly changed.

\begin{tabular}{|c|c|c|}
\hline $\begin{array}{l}\text { Shifts related to glacial } \\
\text { cycles }\end{array}$ & $\begin{array}{l}\text { Geographical effects on } \\
\text { island/archipelago setting }\end{array}$ & $\begin{array}{l}\text { Biogeographical conse- } \\
\text { quences }\end{array}$ \\
\hline Sea level & $\begin{array}{l}\text { Area, elevation and isolation } \\
\text { shifts } \\
\text { Fusion/fission of nearby } \\
\text { islands } \\
\text { Sea mounts emersion/ } \\
\text { submersion }\end{array}$ & $\begin{array}{l}\text { Shifts in area availability and } \\
\text { connectivity, affecting } \\
\text { immigration and } \\
\text { extinction rates } \\
\text { Genetic dilution/allopatric } \\
\text { speciation } \\
\text { Availability/unavailability of } \\
\text { stepping stones }\end{array}$ \\
\hline $\begin{array}{l}\text { Climate (temperature, } \\
\text { precipitation) }\end{array}$ & $\begin{array}{l}\text { Shifts in the vertical } \\
\text { temperature/precipitation } \\
\text { gradients } \\
\text { Shifts in the elevation of the } \\
\text { cloud-sea influence zone }\end{array}$ & $\begin{array}{l}\text { Elevation shifts of zonal } \\
\text { ecosystems } \\
\text { Contractions/expansions of } \\
\text { species distribution ranges } \\
\text { Emergence/disappearance of } \\
\text { summit ecosystems } \\
\text { Species extinctions }\end{array}$ \\
\hline $\begin{array}{l}\text { Marine currents and wind } \\
\text { regimes (frequency, } \\
\text { intensity, direction) }\end{array}$ & $\begin{array}{l}\text { Changes in } \\
\text { mainland-archipelago, } \\
\text { between-archipelago and } \\
\text { within-archipelago } \\
\text { connectivity }\end{array}$ & $\begin{array}{l}\text { Opening/closure of bizarre } \\
\text { windows of dispersal } \\
\text { Boomerang events } \\
\text { Changes in marine species } \\
\text { distributions }\end{array}$ \\
\hline
\end{tabular}

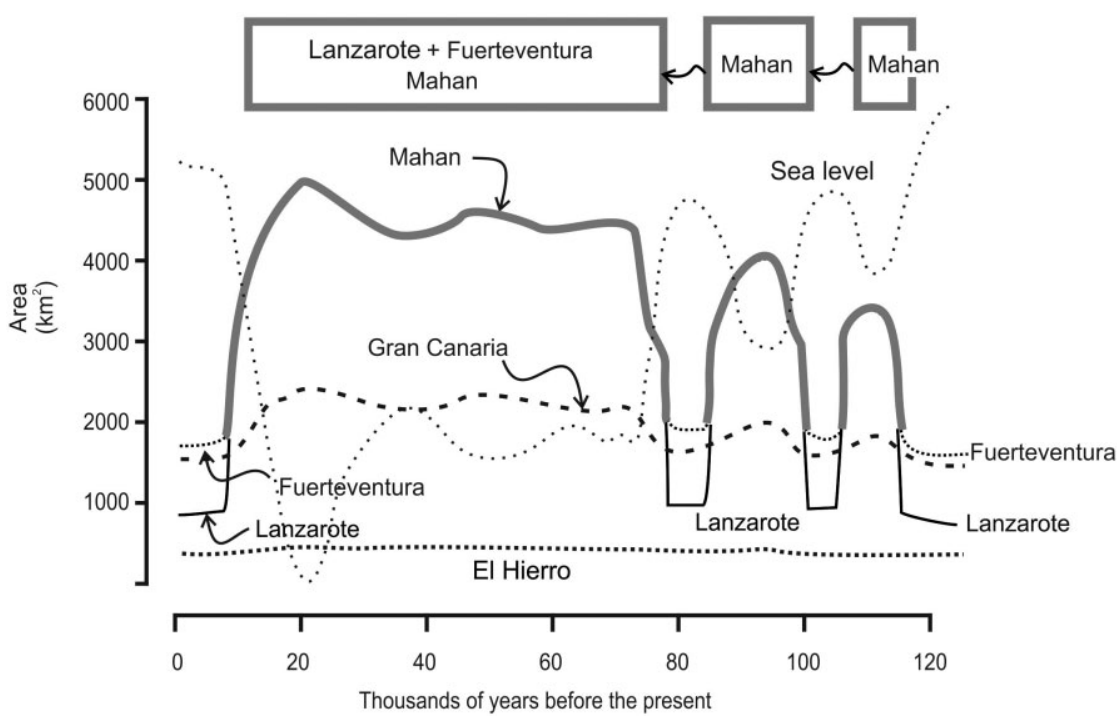

ing islands, as has happened in the Canaries with the appearance of Mahan - the result of the fusion of Lanzarote, Fuerteventura and nearby islets (Fig. 3) (Fernández-Palacios et al., 2011).

Examples of true oceanic islands subject to doubling in area during Pleistocene sea level minima, include: in the Macaronesian region, the Canarian example (see above), Santa Maria (the Azores), Porto Santo (Madeira), Boa Vista and Maio (Cape Verde). Cases of island fusion also include Lauri-insula (the merging of Pico and Faial in the Azores), Pleistocene Madeira (Madeira and Desertas in Madeira) and the NorthWestern Pleistocene Island (Sao Vicente, Santa Luzia, Branco and Raso) in Cape Verde (Rijsdijk et al., 2014). In the Caribbean, the present Leeward Islands of St Martin, Anguilla and St Barthelemy (today covering an area of $200 \mathrm{~km}^{2}$ ) would have formed the St Martin Bank, a single island of approximately $6000 \mathrm{~km}^{2}$ (Woods \& Sergile, 2009). In the East Pacific, during the Last Glacial Maximum (LGM), the central Galápagos islands would have been considerably larger, but without coalescing into a single massif. Nevertheless, Ali \& Aitchison (2014) suggest the main Galápagos islands (Santa Cruz, Santiago, Isabela and Fernandina) formed a single large island as a result of an extreme low sea level stand around $255 \mathrm{ka}$. In the Central Pacific, the Hawaiian islands of Moloka'i, Lana'i, Maui and Kaho'olawe 


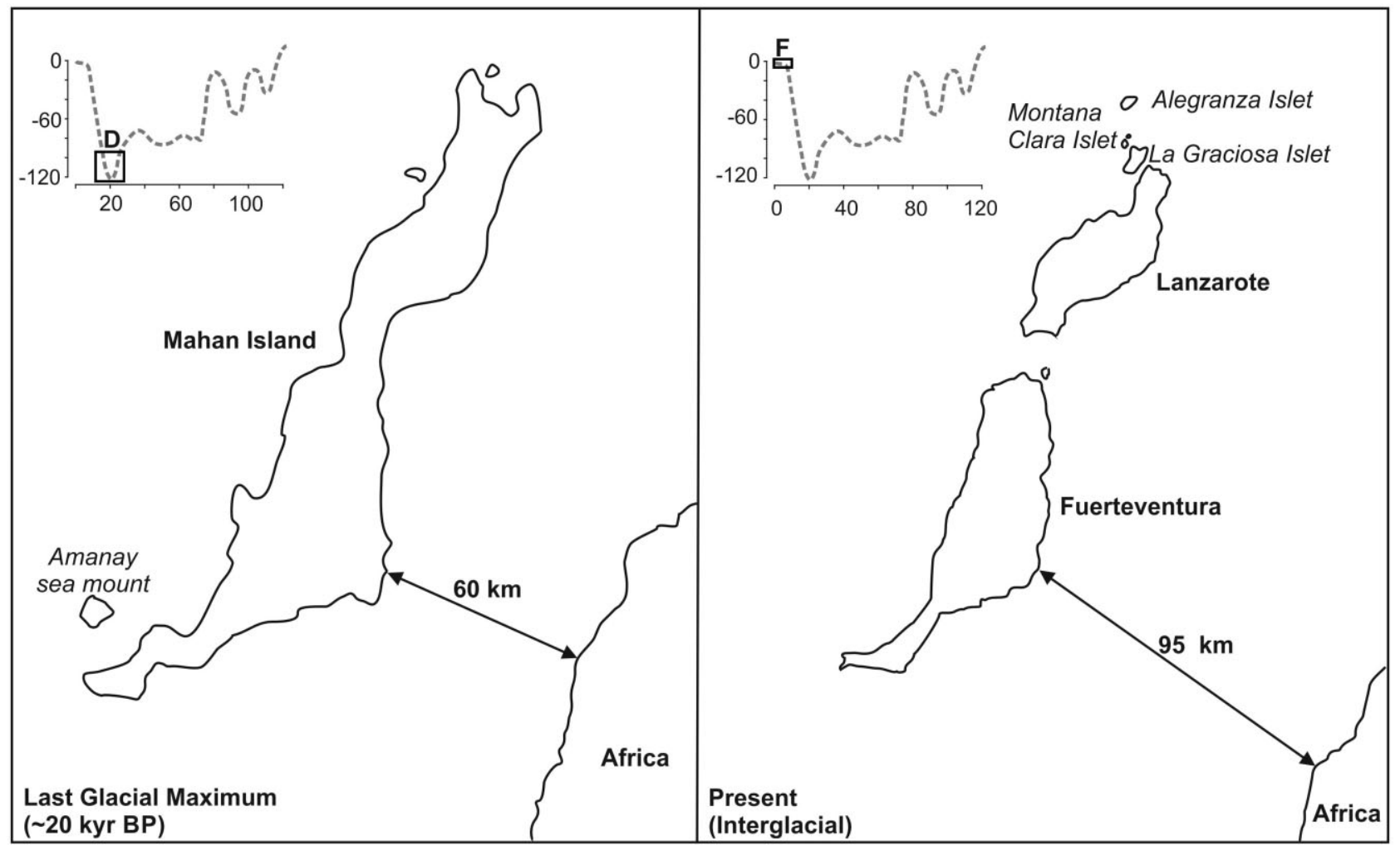

Figure 3 Transition from Mahan (at the Last Glacial Maximum, LGM) to Fuerteventura, Lanzarote and islets (present east Canaries). The islands have undergone fission, halving their emerged area and increasing their distance to Africa due to sea level rise. In the inset graph the oscillation of the sea level (as in Fig. 1) is represented. The last formation of Mahan and the last emergence of Amanay coincided with the LGM (period D in Fig. 1), whereas the splitting in Lanzarote, Fuerteventura and the islets surrounding them and the submersion of Amanay began during the deglaciation period until achieving the present geographical configuration in the beginning of the Holocene (period F). See text for a further explanation.

were joined during the mid Pleistocene, forming Maui Nui. As the area underwent tectonic subsidence, the islands became isolated during high sea stands of interglacial periods, starting around 0.6 Ma. However, during low sea stands, the islands reunited (Price \& Elliot-Fisk, 2004). Finally, in the western Indian Ocean, many islands would have been much larger during the LGM: the Seychelles, today comprising several islands and islets totalling $220 \mathrm{~km}^{2}$, would have formed a single land mass (Granitic Seychelles) of $>40,000 \mathrm{~km}^{2}$ (Warren et al., 2009) (Table 3). Here we expect that nearby islands subject to fusion/fission cycles will share more species than comparable island groups that were never physically linked (Prediction 2a in Box 1). But on the other hand, we also expect that genetic analyses will show that divergence has occurred among populations that were split (allopatry) when islands separated during the interglacial periods (Prediction 2b).

Sea mounts residing in relatively shallow waters would have emerged during a regression, leading to a primary colonization process lasting up to a few thousand years, depending on the duration of the low stand and the depth of the sea mount. These sea mounts would become submerged again during the following transgression, leading to the extinction of all their terrestrial biota (Prediction 3b). The temporary existence of sea mounts must have improved connectivity within archipelagos, between archipelagos and between mainlands and archipelagos. Examples from the eastern Atlantic Ocean include Formigas (in the Azores), Ormonde, Ampere and Siene (in Madeira) or Dacia, Conception and Amanay (in the Canaries) (Fernández-Palacios et al., 2011). In the Indian Ocean the drop in sea level at the LGM resulted in the emergence of the submarine banks of Saya de Malha and Nazareth, located between the Seychelles and Mascarenes in the Madagascan region, forming land areas of approximately 26,500 and $22,000 \mathrm{~km}^{2}$, respectively (Warren et al., 2009).

Such changes in area and isolation over the course of the last glacial cycle (i.e. from the last one, the Eemian, 130-120 ka, to the present interglacial, the Holocene, $11-0 \mathrm{ka}$ ), as exemplified for the Canaries in Figs 2 \& 3, should greatly affect colonization rates and possibly cause a rescue effect, preventing extinctions, as well as a target-area effect enhancing immigration (Predictions $1 \mathrm{a}$ and $1 \mathrm{~b})$. In summary, sea level change will, on an island-by-island basis, have affected area, shape, maximum elevation, isolation, connectivity, coastal perimeters and the elevational distribution of the zonal ecosystems, potentially including the emergence and disappearance of the highest summit ecosystems (see below). We may therefore infer that 
Towards a glacial-sensitive model of island biogeography

Table 3 Area increase during the Last Glaciation Maximum (LGM) in comparison with the present area for selected islands or island groups (see sources in the main text).

\begin{tabular}{|c|c|c|c|c|}
\hline Island or island group & $\begin{array}{l}\text { Present area } \\
\left(\mathrm{km}^{2}\right)\end{array}$ & LGM islands & $\begin{array}{l}\text { Approximate LGM } \\
\text { area }\left(\mathrm{km}^{2}\right)\end{array}$ & $\begin{array}{l}\text { Times larger } \\
\text { than present }\end{array}$ \\
\hline Isabela, St Cruz Fernandina, islets (Galápagos) & 6270 & Large Isabela & 10,000 & $1.6^{*}$ \\
\hline Fuerteventura, Lanzarote, islets (Canaries) & 2500 & Mahan & 5000 & $2.0^{*}$ \\
\hline Maui, Lanai, Molokai (Hawaii) & 2884 & Maui Nui & 6000 & $2.1^{\star}$ \\
\hline Boavista (Cape Verde) & 600 & Boavista Bank & 2700 & 4.5 \\
\hline Porto Santo (Madeira) & 65 & Porto Santo Bank & 250 & 3.8 \\
\hline Rodrigues (Mascarenes) & 109 & LGM Rodrigues & 1200 & 11.0 \\
\hline St Martin, Anguilla, St Barthelemy (Lesser Antilles) & 200 & St. Martin Bank & 6000 & $30.0^{*}$ \\
\hline Seychelles & 220 & Granitic Seychelles & 40,000 & $181.8^{*}$ \\
\hline
\end{tabular}

${ }^{\star}$ The increment in area implied the fusion of several current islands.

these changes will have had a significant role in the rates and patterns of species colonization and extinction, thus driving changes in distributions and in evolutionary forcing. Furthermore, Holocene sea level variation, caused by glacial melting since the end of the last glaciation, has forced the displacement of lowland vegetation, as exemplified by the retreat and expansion of mangroves in the Cook Islands (Ellison, 1994) and Tonga (Fall, 2005), the formation of coastal plains and associated wetland vegetation in Hawaii (Athens \& Ward, 1993), the replacement of littoral forests by heath and grasslands in Madagascar (Virah-Sawmy et al., 2009) and the eventual presence of wetland vegetation in coastal lowlands in Mauritius (de Boer et al., 2014).

\section{Shifts in climate factors controlling the elevational distribution of zonal ecosystems}

Vegetation changes favoured by climate amelioration since the end of the late glacial have been best documented for highlatitude and high-elevation islands, involving, for example, forest expansion (McGlone, 2002; Hannon et al., 2003) and the establishment of modern vegetation after retreat of the ice (Miller et al., 2005).

Patterns of elevational migration of plant species following climate change are reflected by pollen sequences in high islands including Madagascar (2876 m a.s.l.; Gasse \& van Campo, 1998), New Guinea (4884 m a.s.l.; Haberle, 1998), Corsica (2706 m a.s.l.; Reille et al., 1999), Maui (3055 m a.s.l.; Burney et al., 1995) and Taiwan (3952 m a.s.l.; Liew et al., 2006). However, such vertical displacements of vegetation may be limited on islands, especially in the lower ones. In Mauritius (828 $\mathrm{m}$ a.s.l.), alternation from wet to drier periods resulted in high turnover of mountain forest species. Since the late glacial, vegetation has shifted from a stable open forest to a series of forest transitions, occurring during the early Holocene, and finally to a new stable closed-stratified forest from the mid to late Holocene (de Boer et al., 2013). The shift in vegetation at the onset of the Holocene was initially driven by climate but then by natural forest dynamics, as shown by the fast replacement of tree species in the pollen diagram. This forest succession has been proposed as an alternative mechanism to elevational migration in response to climate change for islands that present a relatively low elevation (de Boer et al., 2013).

In oceanic islands, the variation in the main climatic factors (such as mean annual temperature or annual precipitation) in combination with the glacial cycles must have enforced the elevational redistribution of the species and ecosystem ranges (Prediction 4a). In contrast to at least some continental contexts, the potential for vertical migration on high volcanic islands should limit the number of extinctions during periods of climate change. This inference is consistent with the observation that in several cases palaeo-endemic species have persisted relatively unchanged on oceanic islands while disappearing from their source regions. Examples include the laurel-forest tree species that colonized Macaronesia from Europe (Postigo Mijarra et al., 2009) or the tree-fern thicket species of St Helena that reached this island from Africa, although they were later extinguished there due to aridification of the climate (Cronk, 1992).

Even without changes in temperature regime, sea level declines of up to $120 \mathrm{~m}$ would increase the overall elevation range of any island by an equivalent amount. However, besides the drop in sea level, temperatures decreased significantly (Braconnot et al., 2007), so that two factors, fall in sea level and the regional temperature drops coinciding with it, should be considered. A new summit ecosystem may emerge on an island when a glaciation causes the temperatures to decrease. Here pre-adapted species will be favoured in the colonization of these new emerged summits, whether located in the same or a different island. As a counterpoint to the foregoing, rising temperatures during interglacial periods may be expected to result in the reduction or disappearance of prevailing summit ecosystems (Fernández-Palacios et al., 2014), so that some very rare species should present signs of having experienced a demographic collapse caused by climate-driven range contraction (Prediction 4b). We also predict that on some islands currently lacking ice sheets, geomorphological evidence will reveal their presence in the past (Prediction 4c). However, on islands with maximum elevations above the climatic snow line, both the timber line and the snow line are pushed synchronously upwards (during 
interglacials) or downwards (during glacials), so that the upper elevational zones shift up and down without entirely disappearing at any point, while experiencing a change in total area and the degree of habitat fragmentation.

Such zonal shifts are largely temperature driven but are also affected by changes in precipitation and cloud cover. Furthermore, temporal shifts between wetter and dryer conditions may also allow for the immigration or extinction of species or even the appearance or disappearance of vegetation formations or whole ecosystems. Finally, on conically shaped volcanic islands in particular, simultaneously rising sea levels and upwardshifted climatic zones may be expected to have led to both a reduction of total surface area and an upslope shift of ecological zones, resulting in a reduction of both lowland and upland habitat areas and probably in a reduction of carrying capacity for some biota (Figs. 4, 5 and 6).

\section{Shifts in direction, frequency and intensity of marine currents and wind systems affecting the connectivity of the target islands}

It has long been argued that glacial events may have played a significant role in opening new windows of opportunity for long-distance dispersal (LDD), temporarily allowing for dispersal routes that may appear otherwise unlikely (Wallace, 1880). In the Canarian region, where synoptic climate is currently dominated by the north-eastern trade winds and the north-east Canarian marine current, an opposing dispersal route may have existed during the last glacial period (Rognon \& Coudé-Gaussen, 1996). This route, created by reversed winds and currents, would have facilitated the colonization of the African continent from the Canaries, and thus may offer an explanation for the origin of some African endemic species intermingled within Macaronesian phylogenetic clades (termed boomerangs) (Carine et al., 2004; Caujapé-Castells, 2004; Fernández-Palacios et al., 2013) (Predictions 3a and 5a).

Recently published coupled-model simulations for the LGM predict a substantial shift of the Northern Hemisphere westerlies towards the equator along with a $3{ }^{\circ} \mathrm{C}$ cooling at $7^{\circ} \mathrm{N}$ and a $6^{\circ} \mathrm{C}$ cooling at $11^{\circ} \mathrm{N}$ (Williams \& Bryan, 2006). Along the same lines, Rognon \& Coudé-Gausen (1996) asserted nearly two decades ago that several geomorphological features of Canarian and Maghrebian natural landscapes indicate the dominance of westerly wind regimes across the MadeiranCanarian latitudes $\left(25-30^{\circ} \mathrm{N}\right)$ during the glacial periods in the Pleistocene, due to an extreme southward shift of the Azores high-pressure field because of the increased pressures exerted by the North Polar Front. Under these altered synoptic conditions, the unusual retrocolonization events from the Macaronesian islands to the continents become readily explainable. Similar shifts of westerlies in the Southern Hemisphere affecting New Zealand, the sub-Antarctic islands (McGlone et al., 1995) and Tristan da Cunha (Ljung \& Björck, 2007) have been reported. However, in the absence of precisely dated examples we cannot be sure if actual colonization events coincided with these periods. Finally, it should be noted that glacial

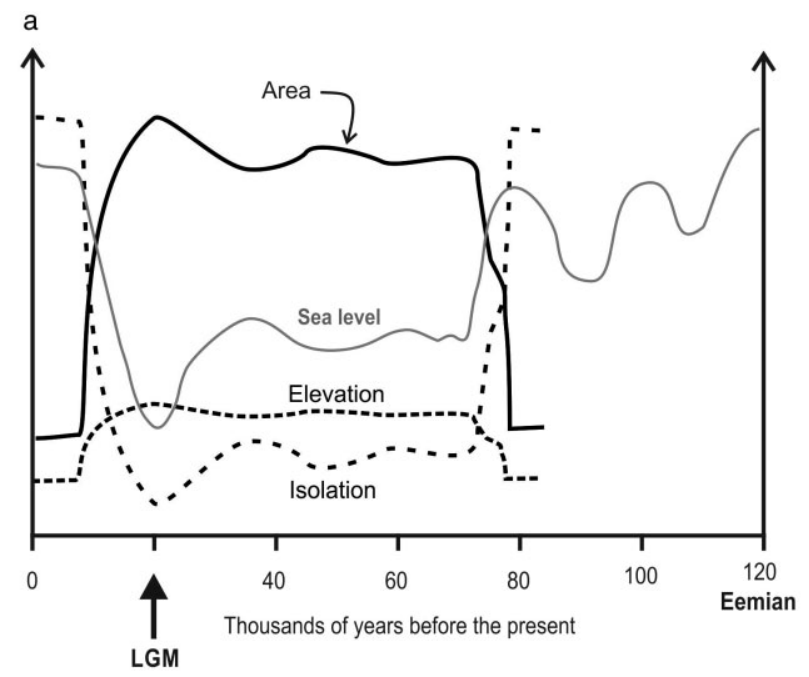

$\mathrm{b}$

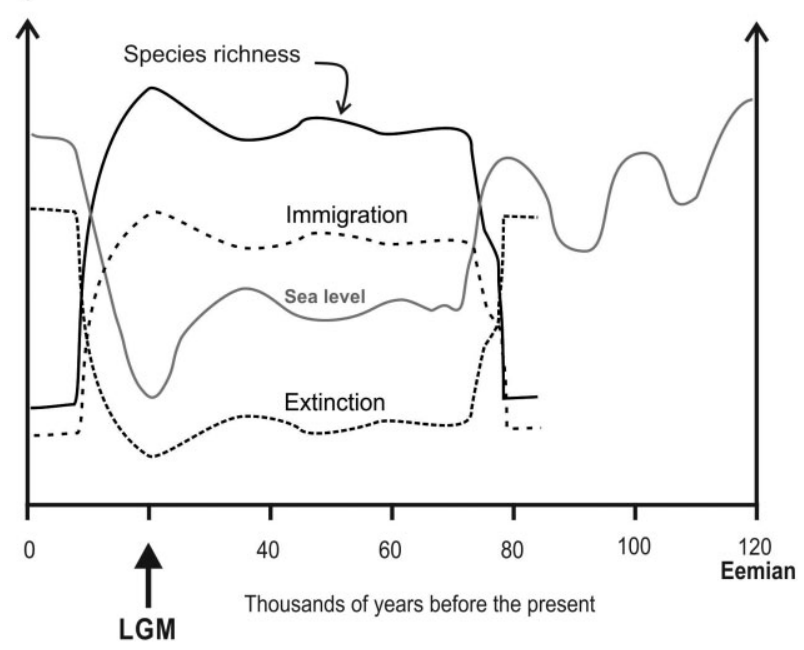

Figure 4 (a) Hypothesized variation of geographical parameters (area, elevation and isolation) of old oceanic islands during the most recent glacial cycle, from the Eemian (130-120 ka) to the Holocene. The trajectories have been kept simple for pedagogic reasons. In reality each of these trajectories should have been adjusted to take account of lag effects and to the precise timing of the most recent glacial cycle (see Fig. 1). (b) Hypothesized variation of biogeographical factors (immigration, extinction and species richness) on old oceanic islands during the most recent glacial cycle, comprising from the Eemian (130-120 ka) to the Holocene. Again, the trajectories have been simplified.

events may also have modified the frequency and/or intensity of important periodic climatic events shaping the present biota and ecosystem structure and dynamics of oceanic islands, as has been recorded in recent decades in the Galápagos, under the influence of pronounced El Niño-Southern Oscillation events (Tudhope et al., 2001).

\section{TRAJECTORIES OF RELEVANT FACTORS DURING A GLACIAL CYCLE}

To encapsulate key features of the above, we provide (Fig. 4a) a general schematic indicating the change in area, elevation and 


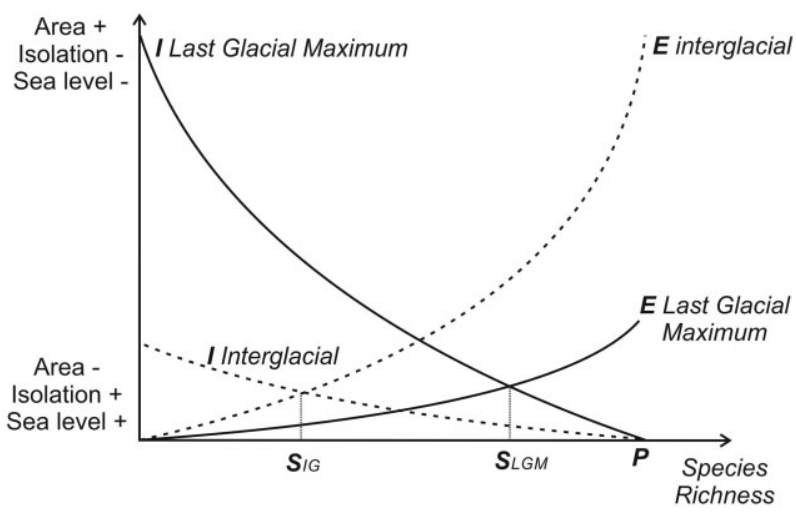

Figure 5 Proposed glacial-sensitive model of island biogeography. The main difference from the MacArthur \& Wilson ETIB model (1967) is that instead of representing only a 'snapshot' of a single set of immigration and extinction rates of initially inhabited and geographically static islands, this model incorporates two sets of rates resulting from a glacial period and an interglacial period respectively, for the same island. The projection onto abscissa from where the immigration rate $(I)$ and extinction rate $(E)$ curves intersect, represents the island species richness expected for this climatic context, whether a glacial or interglacial. It should be noted that only these two intersection points are time-coherent, whereas the other two are just artefacts of the drawing procedure. Although in some cases the degree of change in island area and isolation can be large, for instance in older islands such as the granitic Seychelles, Mahan, Boa Vista or Porto Santo, we expect this effect to be rather small in younger islands. $S_{\mathrm{IG}}$ and $\mathrm{S}_{\mathrm{LGM}}$ refer to species richness at equilibrium for the interglacial and Last Glacial Maximum, respectively; $P$ represents the mainland species pool, which may also change in value between the two periods (not illustrated). See text for further explanation.

isolation of an oceanic island of middling age and stage during the LGM. We assume in this schematic that there has been no volcanic/geomorphic activity affecting island area or elevation and we have made no attempt to incorporate isostatic effects or island subsidence/uplift (cf. Ali \& Aitchison, 2014). The schematic proposes that area and elevation are maximal and isolation is minimal at the point of the LGM sea level minimum, which occurred around $20 \mathrm{ka}$ (Lambeck et al., 2002; Camoin et al., 2004), with the post-glacial eustatic sea level increase generating reduced area and elevation, in tandem with increased isolation. Area and elevation are somewhat lower for the Eemian than currently, whereas isolation is slightly higher, indicating that during this period (the previous interglacial) sea level was somewhat $(8-10 \mathrm{~m})$ higher than in the late Holocene (Camoin et al., 2004).

If we now recall that we often (as in the ETIB) use area as a proxy for extinction and isolation as a proxy for immigration, and also acknowledge that elevation (or elevational range) affects species richness, we hypothesized that according to the changes in those geographical parameters, immigration, extinction and species richness on an island have also fluctuated through the last 130 kyr. For this period, changes in immigra- tion and extinction rates are hypothesized to be symmetrically opposed, with maximum immigration rates at the LGM, when extinction rates are minimal, and maximum extinction rates in the interglacial periods, when immigration rates are minimal (Fig. 4b) (Predictions la and 1b). Species richness is expected to show a similar trajectory as the immigration rate curve, being highest during the glacial maxima and diminishing towards the interglacial due to the occurrence of natural extinctions, caused by area reduction following sea level transgressions (Prediction 1c). Furthermore, we hypothesized that some very rare species should present signs of having passed a demographic collapse $c$. 15-12 ka, resulting from range contraction due to sea level rise (Prediction 1d).

It is important to say that this will mostly affect old islands that have developed a surrounding platform, due to their erosion. The area of young islands (and to a lesser degree their isolation) will be relatively little affected by the glaciations.

The same reasoning applies to guyots, with the difference that the geographical factors affecting them will depend on the sea mount-summit depth, because in interglacial or interstadial periods, area, elevation, immigration and species richness of terrestrial taxa will be zero when the sea mount is submerged. Sea mounts also act as islands for marine species, and their carrying capacity for the benthic communities in particular can also be expected to change in relation to changing sea level as the area of the sea mount within the photic zone changes (cf. Hart \& Pearson, 2011).

Quantitative adjustments to models in the light of the foregoing would require careful estimation because the response of sea level to climate change is not instantaneous, so the correspondence between climate phase and sea level maxima or minima shows some lag effects; furthermore, different cold and warm phases locked up different amounts of ice, and so a sea mount might emerge in some cold periods but not all; and may disappear in some warm periods but not all (Lambeck et al., 2002; Edwards, 2006). Nevertheless, we suggest that our hypothesis provides a general framework of predictions (see Box 1) that can potentially be tested for signals in immigration, extinction, genetic diversity, population bottlenecks and endemism.

\section{TOWARDS A GLACIAL-SENSITIVE MODEL OF ISLAND BIOGEOGRAPHY}

If we consider the implications of these changes in island properties in terms of the classic ETIB diagram of MacArthur \& Wilson (1967), we may predict adjustments in the rates of immigration and extinction (Fig. 5), and by extension implications for the rates of evolutionary processes relating to the extent and degree of fragmentation, isolation and rejoining of major habitat types (not shown in Fig. 5). The main difference is that instead of representing only a 'snapshot' of a single set of immigration and extinction rates of a geographically static island (MacArthur \& Wilson, 1967), this graph incorporates two sets of rates resulting from a glacial period and an interglacial period, respectively, for the same island. In the first scenario, the immigration rate $(I)$ will be higher during the glacial period due to 

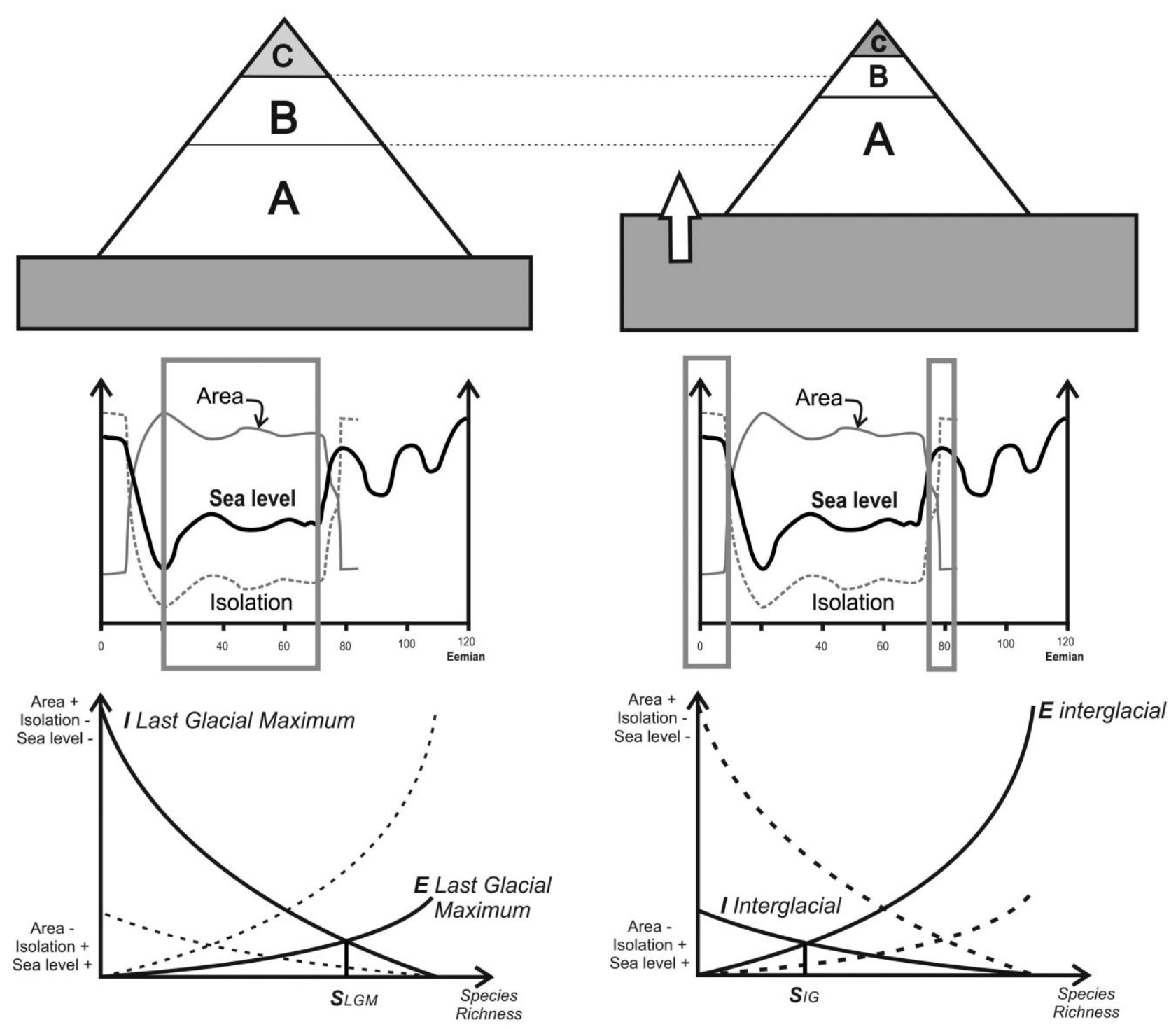

Figure 6 On conically shaped volcanic islands, the transition from glacial maxima, where the island area is greater, the isolation lower (inset graph as in Fig. 4a) and the species richness expected to be higher (inset graph as in Fig. 5), to interglacial stages, where the island area is smaller, isolation higher (inset graph as in Fig. 4a) and species richness expected to be lower (inset graph as in Fig. 5). These shifts will be linked to rising sea levels and upward-shifted climatic zones, which may have resulted in a reduction of both lowland and upland habitat areas and a reduction of the carrying capacity for some biota.

the lower degree of isolation of the island, both because of increased connectivity and an improved target-area effect (due to its larger size). In the second scenario, the extinction rate $(E)$ will be higher during interglacial periods, both because of smaller island area and because increased isolation causes a diminished rescue effect. The projection onto the abscissa from where the immigration-rate and extinction-rate curves intersect, represents the island species richness expected for the particular stage (glacial/interglacial). The projection onto the ordinate represents the expected species turnover. It should be noted that only these two intersection points are time-coherent, whereas the other two are just artefacts of the drawing procedure.

It should be clearly stated that our model only considers the impact on the biota of the island's area and the isolation shifts due to fluctuations in sea level related to glacial cycles, and not the climatic conditions (and ocean/atmospheric systems) that will influence these islands during those periods. For instance, we do know that in the case of high-latitude islands, extensive ice cover during glacial periods has caused significant depressions of diversity (Alsos et al., 2005). On the other hand, isolation may also have decreased due to the formation of ice bridges between islands. For instance, the extinct Falkland Islands wolf, Dusicyon australis, seems to have reached those islands from the Argentinean mainland through an ice bridge that was formed between them during a sea level low stand (Austin et al., 2013). Similarly, a role has been inferred for sea-ice-mediated colonization of Iceland by the Arctic fox (Alopex lagopus) (Mellows et al., 2012).

In general, we consider the model to be most applicable therefore for tropical and subtropical oceanic islands during the 
Towards a glacial-sensitive model of island biogeography

Quaternary. This is not to say that such islands will have been entirely immune from the impacts of climate change during the Pleistocene. For instance, glaciers have formed on Mauna Kea (Hawaii) during cold phases (Porter, 1979), with the consequent elevational reorganization of the vegetation belts (Gavenda, 1992). Elevational movements in response to climate change have also been suggested by palaeo-ecological data elsewhere, for example on Oahu (Hotchkiss \& Juvik, 1999), San Cristóbal (Colinvaux \& Schofield, 1976), Easter Island (Azizi \& Flenley, 2008) and the Mascarenes (De Boer et al., 2013). Furthermore, species in low-lying island biotas would have little chance of escaping towards lower elevations and several insular taxa could have gone extinct.

Nevertheless, even considering that those climatic shifts could have obscured the role of immigration and extinction processes driven by changes in area and isolation, we highlight the potential importance of incorporating sea level shifts in island biogeography models. We also hope that the explicit ecological, genetic, biogeographical and evolutionary predictions generated (see Box 1) will improve the relevance of other theoretical quantitative models of oceanic islands that have recently been developed (Whittaker et al., 2008, 2010; Rosindell \& Phillimore, 2011; Rosindell \& Harmon, 2013).

\section{ACKNOWLEDGEMENTS}

The authors would like to thank Ana Santos, Richard Field and Robert Ricklefs for giving us the opportunity to contribute in the present Special Issue. We also would like to acknowledge the invaluable support and financial help received by La Laguna University Campus de Excelencia, which made possible the celebration in October 2012 of the 1st Macaronesian Palaeoclimate Workshop, where the idea for this paper emerged. R.O. has received support from Campus de Excelencia through a research contract, whereas L.d.N. and S.F.L. are currently contracted by La Laguna University through two different research projects (CGL2012-39369 and AGL-2012-40098-C03-03, respectively) financed by the Spanish Ministerio de Economía y Competitividad. Finally, Don Drake and three anonymous referees have contributed significantly with their comments to the improvement of the present paper.

\section{REFERENCES}

Ali, J.R. \& Aitchison, J.C. (2014) Exploring the combined role of eustasy and oceanic island thermal subsidence in shaping biodiversity on the Galápagos. Journal of Biogeography, 41, 12271241.

Alsos, I.G., Engelskjøn, T., Gielly, L., Taberlet, P. \& Brochmann, C. (2005) Impact of ice ages in circumpolar molecular diversity: insights from an ecological key species. Molecular Ecology, 14, 2739-2753.

Athens, J.S. \& Ward, J.V. (1993) Environmental change and prehistoric Polynesian settlement in Hawai'i. Asian Perspectives, 32, 205-223.
Austin, J.J., Soubrier, J., Prevosti, F., Prates, L., Trejo, V., Mena, F. \& Cooper, A. (2013) The origins of the enigmatic Falkland Islands wolf. Nature Communications, 4, 1552.

Azizi, G. \& Flenley, J.R. (2008) The Last Glacial Maximum climatic conditions on Easter Island. Quaternary International, 184, 166-176.

Bidegaray-Batista, L., Macías-Hernández, N., Oromí, P. \& Arnedo, M. (2007) Living on the edge: demographic and phylogeographical patterns in the woodlouse-hunter spider Dysdera lancerotensis Simon, 1907 on the eastern volcanic ridge of the Canary Islands. Molecular Ecology, 16, 3198 3214.

Bintanja, R., van de Wal, R. \& Oerlemans, J. (2005) Modelled atmospheric temperatures and global sea levels over the past million years. Nature, 437, 125-128.

Bitanja, R. \& van de Wal, R.S.W. (2008) North American ice sheet dynamics and the onset of 100,000-year glacial cycles. Nature, 454, 869-872.

de Boer, E.J., Hooghiemstra, H., Vincent Florens, F.B., Baider, C., Engels, S., Dakos, V., Blaauw, M. \& Bennett, K.D. (2013) Rapid succession of plant associations on the small ocean island of Mauritius at the onset of the Holocene. Quaternary Science Reviews, 68, 114-125.

de Boer, E.J., Tjallingii, R., Vélez, M.I., Rijsdijk, K.F., Vlug, A., Reichart, G.-J., Prendergast, A.L., de Louw, P.G.B., Florens, F.B.V., Baider, C. \& Hooghiemstra, H. (2014) Climate variability in the SW Indian Ocean from an 8000-yr long multi-proxy record in the Mauritian lowlands shows a middle to late Holocene shift from negative IOD-state to ENSO-state. Quaternary Science Reviews, 86, 175-189.

Borges, P.A.V. \& Hortal, J. (2009) Time, area and isolation: factors driving the diversification of Azorean arthropods. Journal of Biogeography, 36, 178-191.

Braconnot, P., Otto-Bliesner, B., Harrison, S. et al. (2007) Results of PMIP2 coupled simulations of the mid-Holocene and Last Glacial Maximum - Part 1: experiments and large-scale features. Climate of the Past, 3, 261-277.

Brown, J.H. \& Kodric-Brown, A. (1977) Turnover rates in insular biogeography: effect of immigration on extinction. Ecology, 58, 445-449.

Bunnefeld, N. \& Phillimore, A.B. (2012) Island, archipelago and taxon effects: mixed models as a means of dealing with the imperfect design of nature's experiments. Ecography, 35, $15-22$.

Burney, D.A., De Candido, R.V., Burney, L.P., Kostel-Hughes, F.N., Stafford, T.W. \& James, H.F. (1995) A Holocene record of climate change, fire ecology and human activity from montane Flat Top Bog, Maui. Journal of Paleolimnology, 13, 209-217.

Cameron, R.A.D., Triantis, K.A., Parent, C.E., Guilhaumon, F., Alonso, M.R., Ibáñez, M., Martins, A.M., Ladle, R.J. \& Whittaker, R.J. (2013) Snails on oceanic islands: testing the general dynamic model of oceanic island biogeography using linear mixed effect models. Journal of Biogeography, 40, 117130. 
Camoin, G.F., Montaggioni, L.F. \& Braithwaite, C.J.R. (2004) Late glacial to post glacial sea levels in the western Indian Ocean. Marine Geology, 206, 119-146.

Carine, M.A., Russell, S.J., Santos-Guerra, A. \& Francisco-Ortega, J. (2004) Relationships of the Macaronesian and Mediterranean floras: molecular evidence for multiple colonizations into Macaronesia and back-colonization of the continent in Convolvulus (Convolvulaceae). American Journal of Botany, 91, 10701085.

Caujapé-Castells, J. (2004) Boomerangs of biodiversity? The interchange of biodiversity between mainland north Africa and the Canary Islands as inferred from cpDNA RFLPs in genus Androcymbium. Botánica Macaronésica, 25, 53-69.

Chen, X. \& He, F. (2009) Speciation and endemism under the model of island biogeography. Ecology, 90, 39-45.

Colinvaux, P.A. \& Schofield, E.K. (1976) Historical ecology in the Galapagos Islands: I. A Holocene pollen record from El Junco Lake, Isla San Cristobal. Journal of Ecology, 64, 9891012.

Cronk, Q.C.B. (1992) Relict floras of Atlantic islands: patterns assessed. Biological Journal of the Linnean Society, 46, 91103.

Diamond, J.M. (1972) Biogeographic kinetics: estimation of relaxation times for avifaunas of southwest Pacific islands. Proceedings of the National Academy of Sciences USA, 69, 31993203.

Edwards, R.J. (2006) Sea levels: change and variability during warm intervals. Progress in Physical Geography, 30, 785-796.

Ellison, J.C. (1994) Palaeo-lake and swamp stratigraphic records of Holocene vegetation and sea level changes, Mangaia, Cook Islands. Pacific Science, 48, 1-15.

Fall, P.L. (2005) Vegetation change in the coastal-lowland rainforest at Avai'o'vuna Swamp, Vava'u, kingdom of Tonga. Quaternary Research, 64, 451-459.

Fernández-Palacios, J.M. (2010) Why islands? Islands and evolution (ed. by V. Pérez Mellado and C. Ramón), pp. 85-109. Institut Menorquí d'Estudis, Maó-Mahón, Spain.

Fernández-Palacios, J.M., de Nascimento, L., Otto, R., Delgado, J.D., García-del-Rey, E., Arévalo, J.R. \& Whittaker, R.J. (2011) A reconstruction of Palaeo-Macaronesia, with particular reference to the long-term biogeography of the Atlantic island laurel forests. Journal of Biogeography, 38, 226-246.

Fernández-Palacios, J.M., Carine, M.A. \& Caujapé-Castells, J. (2013) The importance of windows of opportunity for long-distance dispersal to or from oceanic islands: examples from the Macaronesian archipelagos. Proceedings of the First International Conference on Island Biodiversity (ed. by J. Caujapé-Castells, G. Nieto Feliner and J.M. Fernández-Palacios), pp. 16-23. Fundación Canaria AmurgaMaspalomas/Jardín Botánico Canario Viera y Clavijo, Gran Canaria, Spain.

Fernández-Palacios, J.M., Otto, R., Thebaud, C. \& Price, J.P. (2014) Overview of habitat history in subtropical oceanic island summit ecosystems. Arctic, Antarctic and Alpine Research, 46, 801-809.
Gaina, C., Müller, D.R., Royer, J.Y., Stock, J., Hardebeck, J. \& Symonds, P. (1998) The tectonic history of the Tasman Sea: a puzzle with 13 pieces. Journal of Geophysical Research, 103, 12413-12433.

Gasse, F. \& van Campo, E. (1998) A 40,000-yr pollen and diatom record from Lake Tritrivakely, Madagascar, in the southern tropics. Quaternary Research, 49, 299-311.

Gavenda, R.T. (1992) Hawaiian Quaternary paleoenvironments: a review of geological, pedological, and botanical evidence. Pacific Science, 46, 295-307.

Gilbert, F.S. (1980) The equilibrium theory of island biogeography: fact or fiction? Journal of Biogeography, 7, 209235.

Gilpin, M.E. \& Diamond, J.M. (1976) Calculation of immigration and extinction curves from the species-area-distance relation. Proceedings of the National Academy of Sciences USA, 73, 4130-4134.

González, E.G., Cerón-Souza, I., Mateo, J.A. \& Zardoya, R. (2014) Island survivors: population genetic structure and demography of the critically endangered giant lizard of La Gomera, Gallotia bravoana. BMC Genetics, 15, 121.

Haberle, S.G. (1998) Late Quaternary vegetation change in the Tari Basin, Papua New Guinea. Palaeogeography, Palaeoclimatology, Palaeoecology, 137, 1-24.

Hannon, G.E., Bradshaw, R.H.W. \& Wastegård, S. (2003) Rapid vegetation change during the early Holocene in the Faroe Islands detected in terrestrial and aquatic ecosystems. Journal of Quaternary Science, 18, 615-619.

Hart, P.J.B. \& Pearson, E. (2011) An application of the theory of island biogeography to fish speciation on seamounts. Marine Ecology Progress Series, 430, 281-288.

Heaney, L.R. (1986) Biogeography of mammals in SE Asia: estimates of rates of colonization, extinction and speciation. Biological Journal of the Linnean Society, 28, 127-165.

Heaney, L.R. (2000) Dynamic disequilibrium: a long-term, large-scale perspective on the equilibrium model of island biogeography. Global Ecology and Biogeography, 9, 59-74.

Heaney, L.R., Balete, D.S. \& Rickart, E.A. (2013) Models of oceanic island biogeography: changing perspectives on biodiversity dynamics in archipelagos. Frontiers of Biogeography, $\mathbf{5}$, 249-257.

Hotchkiss, S. \& Juvik, J.O. (1999) A Late-Quaternary pollen record from Ka'au Crater, O'ahu, Hawai'i. Quaternary Research, 52, 115-128.

Johnson, K.P., Adler, F.R. \& Cherry, J.L. (2000) Genetic and phylogenetic consequences of island biogeography. Evolution, 54, 387-396.

Kearey, P., Klepeis, K.A. \& Vine, F.J. (2009) Global tectonics, 3rd edn. Wiley-Blackwell, Chichester.

Lambeck, K., Esat, T.M. \& Potter, E.-K. (2002) Links between climate and sea levels for the past three million years. Nature, 419, 199-206.

Liew, P.-M., Huang, S.-Y. \& Kuo, C.-M. (2006) Pollen stratigraphy, vegetation and environment of the last glacial and Holocene - a record from Toushe Basin, central Taiwan. Quaternary International, 147, 16-33. 
Ljung, K. \& Björck, S. (2007) Holocene climate and vegetation dynamics on Nightingale Island, South Atlantic - an apparent interglacial bipolar seesaw in action? Quaternary Science Reviews, 26, 3150-3166.

Lomolino, M.V. (1990) The target area hypothesis: the influence of island area on immigration rates on non-volant mammals. Oikos, 57, 297-300.

Lomolino, M.V. (2000) A call for a new paradigm of island biogeography. Global Ecology and Biogeography, 9, 1-6.

MacArthur, R.H. \& Wilson, E.O. (1963) An equilibrium theory of insular zoogeography. Evolution, 17, 373-387.

MacArthur, R.H. \& Wilson, E.O. (1967) An equilibrium theory of island biogeography. Princeton University Press, Princeton.

McGlone, M.S. (2002) The Late Quaternary peat, vegetation and climate history of the Southern Oceanic Islands of New Zealand. Quaternary Science Reviews, 21, 683-707.

McGlone, M.S., Mark, A.F. \& Bell, D. (1995) Late Pleistocene and Holocene vegetation history, Central Otago, South Island, New Zealand. Journal of the Royal Society of New Zealand, 25, $1-22$.

Macqueen, P., Goldizen, A.W., Austin, J.J. \& Seddon, J.M. (2011) Phylogeography of the pademelons (Marsupialia: Macropodidae: Thylogale) in New Guinea reflects both geological and climatic events during the Plio-Pleistocene. Journal of Biogeography, 38, 1732-1747.

Mellows, A., Barnett, R., Dalén, L., Sandoval-Castellanos, E., Linderholm, A., McGovern, T.H., Church, M.J. \& Larson, G. (2012) The impact of past climate change on genetic variation and population connectivity in the Icelandic arctic fox. Proceedings of the Royal Society B: Biological Sciences, 279, 4568-4573.

Miller, G.H., Wolfe, A.P., Briner, J.P., Sauer, P.E. \& Nesje, A. (2005) Holocene glaciation and climate evolution of Baffin Island, Arctic Canada. Quaternary Science Reviews, 24, 17031721.

Porter, J. (1979) Hawaiian glacial ages. Quaternary Research, 12, 161-187.

Postigo Mijarra, J.M., Barrón, E., Gómez Manzaneque, F. \& Morla, C. (2009) Floristic changes in the Iberian Peninsula and Balearic Islands. Journal of Biogeography, 36, 20252043.

Price, J.P. \& Elliott-Fisk, D. (2004) Topographic history of the Maui Nui complex, Hawai'i, and its implications for biogeography. Pacific Science, 58, 27-45.

Reille, M., Gamisans, J., Andrieu-Ponel, V. \& de Beaulieu, J.-L. (1999) The Holocene at Lac de Creno, Corsica, France: a key site for the whole island. New Phytologist, 141, 291-307.

Rijsdijk, K.F., Hengl, T., Norder, S., Otto, R., Emerson, B.C., Ávila, S.P., López, H., van Loon, E., Tjorve, E. \& Fernández-Palacios, J.M. (2014) Quantifying surface area changes of volcanic islands driven by Pleistocene sea level cycles: biogeographic implications for Macaronesian archipelagos, Atlantic Ocean. Journal of Biogeography, 41, 12271439.

Rognon, P. \& Coudé-Gaussen, G. (1996) Paleoclimates off Northwest Africa $\left(28^{\circ}-35^{\circ} \mathrm{N}\right)$ about $18.000 \mathrm{yr}$ B.P. based on continental Eolian deposits. Quaternary Research, 46, 118 126.

Rohling, E.J., Grant, K., Bolshaw, M., Roberts, A.P., Siddall, M., Hemleben, C. \& Kucera, M. (2009) Antarctic temperature and global sea level closely coupled over the past five glacial cycles. Nature Geoscience, 2, 500-504.

Rohling, E.J., Braun, K., Grant, K., Kucera, M., Roberts, A.P., Siddall, M. \& Trommer, G. (2010) Comparison between Holocene and Marine Isotope Stage-11 sea-level histories. Earth and Planetary Science Letters, 291, 97-105.

Rosindell, J. \& Harmon, L.J. (2013) A unified model of species immigration, extinction and abundance on islands. Journal of Biogeography, 40, 1107-1118.

Rosindell, J. \& Phillimore, A.B. (2011) A unified model of island biogeography sheds light on the zone of radiation. Ecology Letters, 14, 552-560.

Schoener, T.W. (2010) The MacArthur-Wilson equilibrium model. The theory of island biogeography revisited (ed. by J.B. Losos and R.E. Ricklefs), pp. 52-87. Princeton University Press, Princeton, NJ.

Shennan, I. \& Horton, B. (2002) Holocene land- and sea level changes in Great Britain. Journal of Quaternary Science, 17, 511-526.

Simberloff, D. (1976) Species turnover and equilibrium island biogeography. Science, 194, 572-578.

Stuessy, T.F. (2007) Evolution of specific and genetic diversity during ontogeny of island floras: the importance of understanding process for interpreting island biogeographic patterns. Biogeography in a changing world (ed. by M.C. Ebach and R.S. Tangney), pp. 117-133. CRC Press, Boca Raton, FL.

Tudhope, A.W., Chilcott, C.P., McCulloch, M.T., Cook, E.R., Chappell, J., Ellam, R.M., Lea, D.W., Lough, J.M. \& Shimmield, G.B. (2001) Variability in the El Niño-Southern Oscillation through a glacial-interglacial cycle. Science, 291, 1511-1517.

Vaxevanidou, Z., González-Martínez, S., Climent, J. \& Gil, L. (2006) Tree populations bordering on extinction: a case study in the endemic Canary Island pine. Biological Conservation, 129, 451-460.

Virah-Sawmy, M., Willis, K.J. \& Gillson, L. (2009) Threshold response of Madagascar's littoral forest to sea level rise. Global Ecology and Biogeography, 18, 98-110.

Voris, H.K. (2000) Maps of Pleistocene sea levels in Southeast Asia: shorelines, river systems and time durations. Journal of Biogeography, 27, 1153-1167.

Wallace, A.R. (1880) Island life or the phenomena and causes of insular faunas and floras, including a revision and attempted solution of the problem of geological climates [with a foreword by David Quammen and an introduction with commentary by Lawrence R. Heaney], 2013 Facsimile edn. University of Chicago Press, Chicago, IL.

Wang, X., Sun, X., Wang, P. \& Stattegger, K. (2009) Vegetation on the Sunda Shelf, South China Sea, during the Last Glacial Maximum. Palaeogeography, Palaeoclimatology, Palaeoecology, 278, 88-97. 
Warren, B.H., Strasberg, D., Bruggemann, J.H., Prys-Jones, R.P. \& Thébaud, C. (2009) Why does the biota of the Madagascar region have such a strong Asiatic flavour? Cladistics, 25, $1-12$.

Warren, B.H., Simberloff, D., Ricklefs, R.E. et al. (2015) Islands as model systems in ecology and evolution: prospects fifty years after MacArthur-Wilson. Ecology Letters, 18, 200-217.

Whelan, F. \& Kelletat, D. (2003) Submarine slides on volcanic islands - a source for mega-tsunamis in the Quaternary. Progress in Physical Geography, 27, 198-216.

Whittaker, R.J. \& Fernández-Palacios, J.M. (2007) Island biogeography: ecology, evolution and conservation, 2nd edn. Oxford University Press, Oxford.

Whittaker, R.J., Bush, M.B. \& Richards, K. (1989) Plant recolonization and vegetation succession on the Krakatau Islands, Indonesia. Ecological Monographs, 59, 59-123.

Whittaker, R.J., Triantis, K. \& Ladle, R.J. (2008) A general dynamic theory of oceanic island biogeography. Journal of Biogeography, 35, 977-994.

Whittaker, R.J., Triantis, K.A. \& Ladle, R.J. (2010) A general dynamic theory of oceanic island biogeography: extending the MacArthur-Wilson theory to accommodate the rise and fall of volcanic islands. The theory of island biogeography revisited (ed. by J.B. Losos and R.E. Ricklefs), pp. 88-115. Princeton University Press, Princeton, NJ.

Wilcox, B.A. (1978) Supersaturated island faunas: a species-age relationship for lizards on post-Pleistocene land-bridge islands. Science, 199, 996-998.
Williams, G.P. \& Bryan, K. (2006) Ice age winds: an aquaplanet model. Journal of Climate, 19, 1706-1715.

Wilson, J.T. (1969) A possible origin of the Hawaii islands. Canadian Journal of Physics, 41, 863-870.

Woods, C.A. \& Sergile, F.E. (2009) Antilles, biology. Encyclopedia of islands (ed. by R.G. Gillespie and D.A. Clague), pp. 20-29. University of California Press, Berkeley, CA.

Wright, S.J. (1985) How isolation affects rates of turnover of species on islands. Oikos, 44, 331-340.

\section{BIOSKETCH}

José María Fernández-Palacios is a Canarian island ecologist and biogeographer with a special interest in the role of recent, but also remote, history in shaping the ecosystems and biota of oceanic islands, with a special focus on the Macaronesian region. He is also active in research into the dynamics of the laurel forest, pine forest and thermophilous woodlands, as well as in the ecological restoration of those ecosystems.

Author contributions: J.M.F.-P., K.F.R. and E.T. developed the idea and manuscript structure. K.F.R. and S.N. produced Figs 1, 2, 3 \& 6, and J.M.F.-P. Figs 4 \& 5. R.O., L.d.N. and S.F.L. revised the bibliography and finally, J.M.F.-P. and R.J.W. led the writing.

Editor: Ana Santos 